\title{
ANALISIS EFEKTIVITAS APLIKASI SISTEM INFORMASI ASET POLRI MENGGUNAKAN METODE TECHNOLOGY ACCAPTANCE MODEL PADA BIRO SARPRAS POLDA JAMBI
}

\author{
$\underline{\text { Mintaria }^{1}, \text { Joni Devitra }}{ }^{2}$ \\ Program Studi Magister Sistem Informasi, STIKOM Dinamika Bangsa, Jambi \\ Jl. Jendral Sudirman, Kec. The Hok, (0741) 35095 \\ E-mail: Adriell_energikus@yahoo.com ${ }^{1}$, devitrajoni@yahoo.co.id ${ }^{2}$
}

\begin{abstract}
In the development of information technology in the goverment and the prive sectors keep on developing a system of information based application. But in fact, there are a lot of application of this system information can not be used effectively buy user. As in the implementantion of property's of the system information on the facilites and infrastructure office Polda Jambi is still less effective to use. It makes the researcher need to research about the effectiveness of application of Polri propertys system of information which is applied in Polda Jambi's office of facilities and infsdtructure (Biro Sarpras Polda Jambi) based on the reasercher's research used Technology Accaptance Model (TAM) as a method, it found that there are 100 respondents filled the questionnaire showed that all of them do not really understand, feel doubt and have no willingness in using that application. So, it makes this application can not be applid effectively.
\end{abstract}

Key words : effecticeness analysis, TAM

\begin{abstract}
Abstrak
Dalam perkembangan Teknologi informasi baik pada lembaga Pemerintah maupun Swasta terus mengembangkan sebuah sistem informasi yang berbasis Aplikasi, Namun pada kenyataannya banyak Aplikasi dari sistem informasi ini tidak dapat dipergunakan secara efektif oleh pengguna akhir atau Operator yang di tugaskan. Seperti pada penerapan Aplikasi Sistem informasi Aset Polri pada biro Sarpras Polda Jambi yang masih dirasakan kurang efektive dalam penggunaan ini, sehingga dalam penelitian ini penulis ingin meneliti tentang efektifitas dari Aplikasi sistem informasi Aset Polri yang diterapkan pada Biro Sarpras Polda Jambi dan Jajaran, dan berdasarkan hasil penelitian yang dilakukan penulis dengan menggunakan metode Tehnology Accaptance model (TAM) diketahui bahwa 100 orang respoden yang mengisi kuesioner mereka merasa kurang memahami dan tidak ada kepercayaan dan minat dalam memanfaatkan Aplikasi Sistem informasi aset Polri sehingga aplikasi ini belum dapat diterapkan secara efektif.
\end{abstract}

Kata-kunci : Analisis Efektivitas, TAM

(C) 2019 Jurnal Manajemen Sistem Informasi.

\section{Pendahuluan}

Setiap organisansi pemerintah maupun swasta tentunya memiliki aset baik yang berwujud (tangible) maupun tidak berwujud (intagible). Setiap aset yang dimiliki haruslah dikelolah dengan efektif dan efisien sehingga aset tersebut dapat memberikan manfaat yang tinggi bagi instansi yang menguasainya. Aset manajemet fisik belum banyak diimplementasikan, banyak instansi yang mengganggap manajement aset secara fisik adalah pengelolaan daftar aset. Padahal manajemen aset bukan hanya menyusun daftar aset tetapi juga menyangkut evaluasi dan penilaian aset yang dapat membuat sistem bisa mengontrol dan menangani perubahan data aset dengan cepat. 
Manajemen aset juga mencari cara untuk mengoptimalkan aktivitas dan penggunaan aset yang memenuhi standar level pelayanan. Pengembangan manajemen berdasarkan pada pengumpulan analisa informasi kunci mengenai aset, kinerja, biaya, masa pakai, biaya penyusutan dan pemeliharaan. Saat ini manajemen Aset banyak diterapkan pada instansi pemerintah maupun swasta salah satunya instansi Kepolisian Negara Republik Indonesia.

Biro Sarana dan Prasarana (RoSarpras) merupakan pembina fungsi Aset barang milik negara diwilayah Polda Jambi, yang meliputi aset bergerak maupun aset tidak bergerak yang tersebar diseluruh wilayah jajaran Polda Jambi dengan jumlah yang dapat berubah sejalan dengan kebutuhan masing-masing satuan kerja. Perubahan jumlah aset sangat perlu diikuti dengan sistem administrasi dan pencatatan yang sangat baik sehingga data aset tersebut valid dan up to date.

Sehubungan dengan hal tersebut Polri menggunakan dan mengembangkan sebuat aplikasiSIAP (Sistem informasi Aset Polri) yang merupakan sebuah aplikasi berbasis web sebagai sarana untuk mempermudah inventory management, pengendalian organisasi, percepatan proses pelaporan dan peningkatan akurasi penyajian data dan informasi baik dari tingkat terendah sampai kepada tingkat pimpinan yang lebih tinggi.

Tetapi didalam penerapan aplikasi SIAP ini belum terlaksana sesuai dengan yang diharapkan dikarenakan berbagai macam faktor yang timbul baik dari pengguna aplikasi maupun dari aplikasi itu sendiri, sehingga tujuan utama dalam pembuatan aplikasi ini belum terlaksana, salah satunya kendala yang dialami Operator yang ditugaskan dalam penginputan data melalui aplikasi ini masih merasa belum mengerti dan menguasai secara benar cara dalam penginputan, pencarian data, dan pencetakan laporan dari Aplikasi SIAP ini.

\subsection{Rumusan Masalah}

a. Dari latar belakang diatas maka rumusan masalahnya adalah sebagai berikut:

b. Bagaimana menganalisis Aplikasi sistem informasi aset Polri pada biro sarpras Polda Jambi

c. Bagaimana melakukan penilaian terhadap efektivitas Aplikasi Sistem informasi Aset Polri.

\subsection{Batasan Masalah}

Adapun batasan masalah yang dapat membantu dalam penyusunan proposal tesis agar tidak menyimpang dari maksud dan tujuan yang ingin dicapai adalah sebagai berikut:

1. Penelitian ini menggunakan metode TAM yang bertujuan untuk melakukan penilaian dari efektivitas aplikasi Sistem informasi Aset Polri.

2. Penelitian ini bertujuan untuk memberikan masukan dan saran kepada pimpinan mengenai hasil yang didapatkan dari penilaian melalui observasi dan kuisoner.

3. Hasil penelitian dalam pengatasi masalah yang ditimbulkan hanya dikembangkan sebatas tahap pembuatan Prototape.

\subsection{Tujuan Penelitian}

Tujuan dari penelitian ini adalah sebagai berikut:

1. Menganalisa Aplikasi system informasi aset Polri pada biro sarpras polda jambi dan jajaran.

2. Melakukan penilaian terhadap efektivitas pengguanaan Aplikasi system informasi Aset pada Biro Sarpras Polda Jambi dan jajaran.

\subsection{Manfaat Penelitian}

Ada pun manfaat dari penelitian ini adalah:

1. Bagi organisasi Terlaksananya pelaporan dan pendataan yang lebih akurat pada setiap aset barang milik negara pada masih-masing satuan kerja.

2. Bagi operator aplikasi dapat memecahkan persoalan-persoalan yang sering terjadi dalam penggunaan aplikasi.

3. Bagi peneliti lain, penelitian ini akan memberikan masukan ilmu bagi jurusan magister system informasi tentang menganalisis efektivitas aplikasi sistem informasi Aset Polri .

\section{Tinjauan Pustaka/Penelitian Sebelumnya}

Penelitian Febri Indra Arza: 2013 tentang Pendekatan technology acceptance model dalam kesuksesan implementasi sistem informasi manajement daerah (jurnal WRA-Volume.1 No.1-April 2013). 
Penelitian Ni nengah Wartini dan I.G.W murjana Yasatentang Analisis efektivitas sistem informasi keuangan daerah (SIKD) pemerintah kabupaten Jembaran(e- Jurnal ekonomi dan bisnis universitas udayana Vol 5, No.25, Maret 2016

Tesis Shinta Eka Kartika :2009 Tentang Analisis Proses penerimaan Sistem informasi iCons Dengan menggunakan Technology Accaptance model pada karyawan PT. Bank Negara Indonesia (PERSERO) TBK. Dikota Semarang

\subsection{Technology Acceptance Model (TAM)}

Technology acceptance model (TAM) pertama kali dikembangkan oleh davis(1989) dan kemudian dipakai serta dikembangkan kembali oleh beberapa peneliti seperti Adam et al.(1992) Szajna (1994), Igbaria et al (1995) dan Venkatesh dan Davis (200. Modifikasi model TAM dilakukan oleh Venkatesh (2002) dengan menambahkan variabel trust dengan judul trust enhanced Technology acceptance model, yang meneliti tenetang variabel TAM dan trust.

TAM merupakan adaptasi dari Theory of Reasoned Action Model (TRA) yang secara khusus telah disesuaikan dengan model penerimaan sistem informasi oleh pengguna/user (Davis et aL,1989). TAM memiliki dua sisi yang yaitu sisi pertama atau yang biasa disebut beliefs yang terdiri atas perceived usefulness dan perceived ease-of use dan sisi yang kedua terdiri dari attitude, behavior intention to use dan usage behavior (Straub, Limayen, Evaristo, 1995 dalam Petra, 2005). Berikut ini adalah gambar tentang TAM :

Gambar 2.1 Hubungan antar komponen dalam TAM

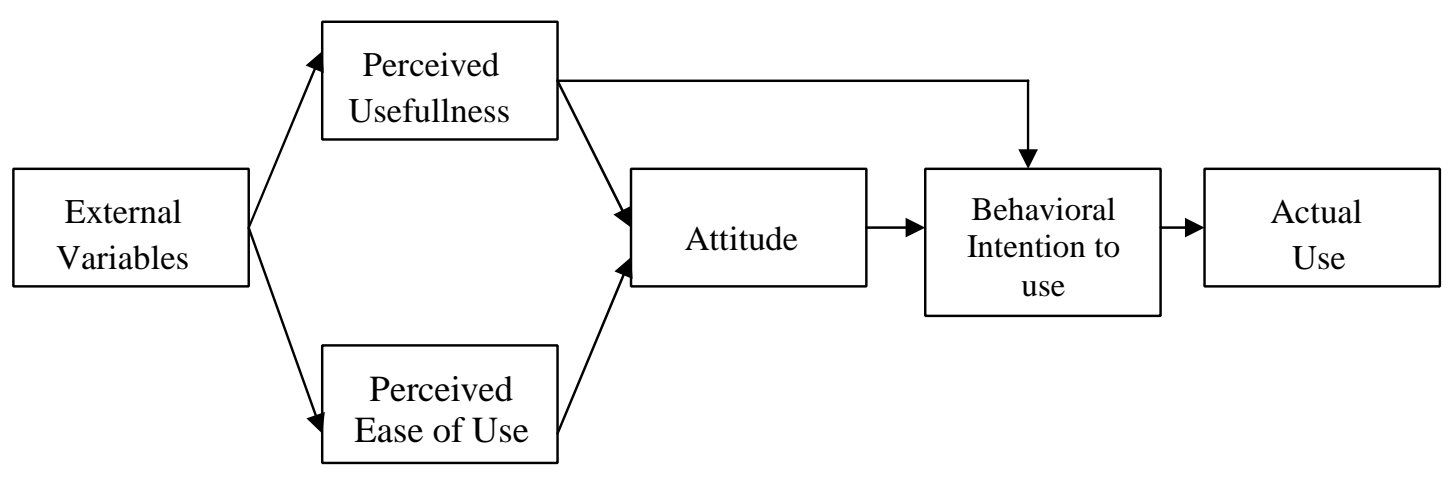

Sumber: Davis (1986) dalam Warshaw et al (1989).

TAM menjelaskan hubungan antara keyakinan/beliefs (usefulness dan ease of use) dengan sikap/attitude, tujuanlintentions pemakai, serta penggunaan nyata dari sistem. Perceived usefulness didefinisikan oleh Davis et al (1989) sebagai suatu tingkat dimana seseorang percaya bahwa penggunaan sistem secara khusus akan meningkatkan kinerjanya. Sedangkan perceived ease of use didefinisikan sebagai suatu tingkat dimana seseorang percaya bahwa penggunaan sistem secara khusus akan mengarah pada suatu usaha. Penelitian Leong (2003) dalam Gardner dan Amoroso (2004) menguji penggunaan MS Acces mengelompokan variabel-variabel dalam TAM menjadi 3 kelompok yaitu Perceived usefulness dan Perceived ease of use sebagai variabel independent, penggunaan sistem secara nyata sebagai variabel dependent dan variabel-variabel mediasinya adalah attitude toward use dan behavioral intention to use.

\section{Theory of Reasoned Action (TRA)}

TRA adalah model yang secara umum menjelaskan dan memprediksi tujuan berperilaku/behavioral intentions pada berbagai setting. Model ini didasarkan atas asumsi bahwa manusia membuat keputusan rasional didasarkan atas informasi yang tersedia pada mereka. Ada tiga komponen dalam model ini yaitu behavioral intention (BI), attitude (A), and subjective norm (SN), BI = A + SN (Fishbein \& Ajzen, 1975 dalam Leong, 2003).

Behavioral intention mengukur kekuatan tujuan untuk melakukan tindakan tertentu. Attitude menggambarkan perasaan positif atau negatif individu (menilai dampak/evaluative affect) tentang kinerja dari target suatu tindakan. Subjective norm mengarah pada persepsi seseorang tentang kebanyakan orang yang akan bertanya mengenai apakah dia harus atau tidak melakukan tindakan tersebut (Fishbein \& Ajzen, 1975, dalam Leong, 2003). 
Gambar 2.2 Theory of Reasoned Action (TRA)

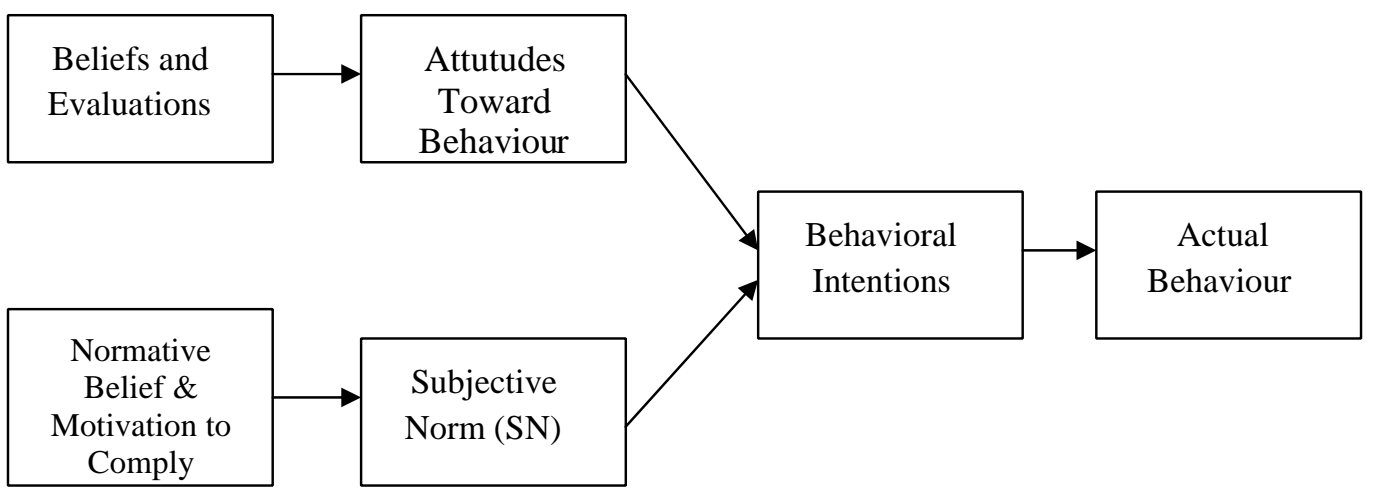

Sumber: Fishbein and Ajzen (1975)

Theory of Reasoned Action Model merupakan model yang banyak diaplikasikan selama ini. Model ini menyatakan perilaku konsumen (B) terprediksi dari niat berperilaku (BI) yang terbentuk melalui suatu proses keputusan yang rasional. Niat berperilaku tersebut merupakan fungsi dari evaluasi keseluruhan tentang sikap terhadap perilaku ( $\mathrm{Ab}$ ), ditambah keyakinan tentang pengharapan-pengharapan dari referen terhadap perilaku seperti itu yang kemudian ditimbang dengan motivasinya untuk menuruti pengharapan - pengharapan tersebut (SN). Sikap terhadap perilaku dibentuk dari kombinasi antara kekuatan (bi) dan evaluasi (ei) tentang keyakinan penting seseorang. Sementara itu norma subyektif merupakan produk dari keyakinan konsumen bahwa orang penting lain (referen) berpendapat ia seyogyanya atau tidak seyogyanya melaksanakan perilaku (NBj). Selain terhadap perilaku, model ini juga dapat dan seringkali diterapkan untuk mengukur sikap terhadap obyek tertentu (Fishbein \& Ajzen, 1975:359). Penjelasan lebih ringkas dapat dilihat pada gambar 2.5 berikut ini :

Gambar 2.3 Theory of Reasoned Action Mode (Fishbein \& Ajezen)

\subsubsection{Model Sikap Bentler dan Speckart}

Sumber: Fishbein and Ajzen (1975)

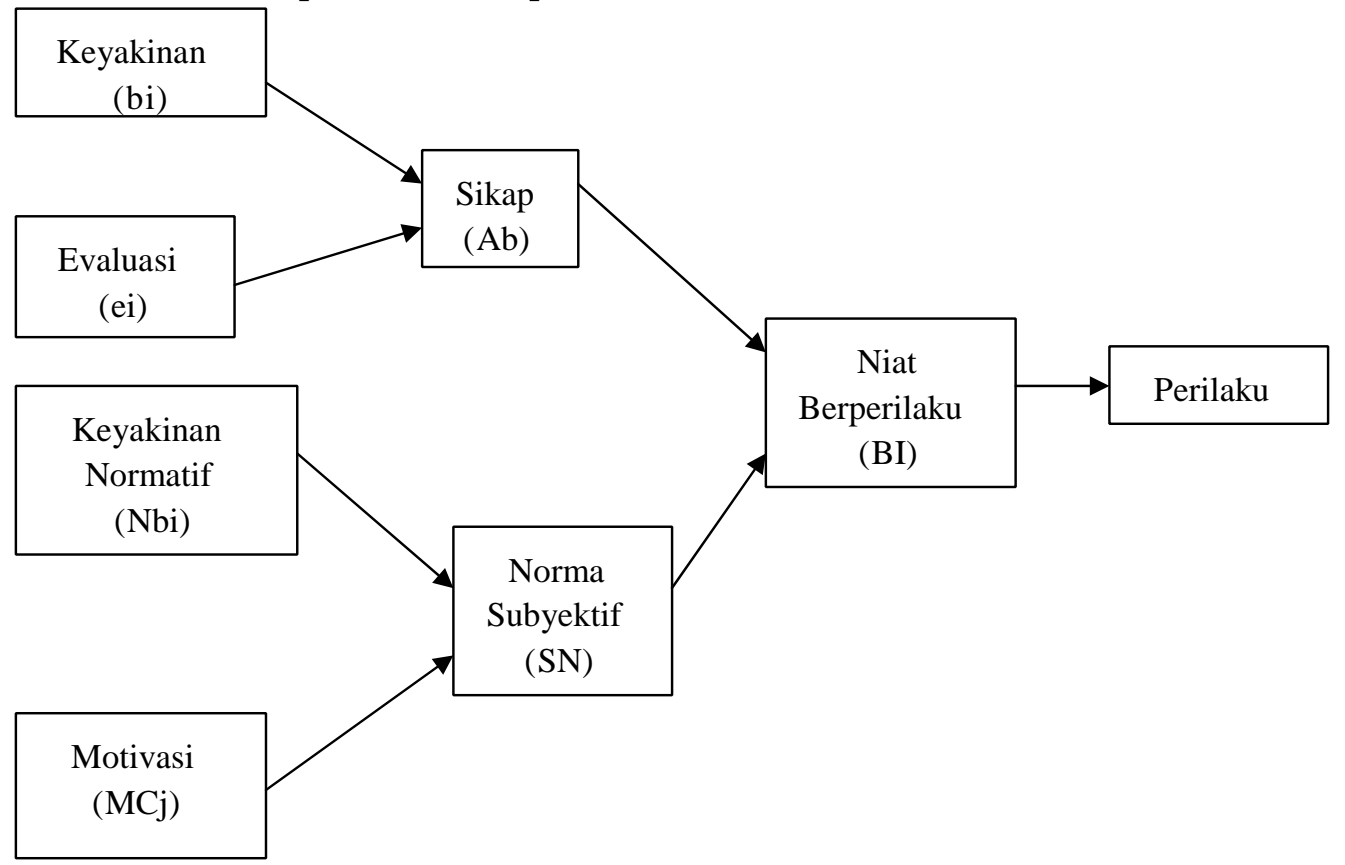

Model sikap yang diusulkan Bentler dan Speckart (1979:452) merupakan perluasan dari teori hubungan sikap-perilaku Fishbein dan Ajzen. Model Bentler dan Speckart menunjukkan bahwa niat selain dipengaruhi oleh faktor sikap dan norma subyektif juga dipengaruhi oleh faktor perilaku sebelumnya. Sebab seberapapun akuratnya pengukuran kita terhadap sikap dan norma subyektif, jika ukuran relatif sikap dan norma subyektif bervariasi pada subyek maka akan tetap ada variasi 
residual dalam niat yang tidak dapat dijelaskan oleh analisis regresi, bahkan jika tidak ada faktor lain selain sikap dan norma subyektif yang mempengaruhi niat, variasi residual ini dapat diprediksi pada tingkat signifikan melalui perilaku lampau. Model ini digambarkan dalam gambar 2.6 berikut ini :

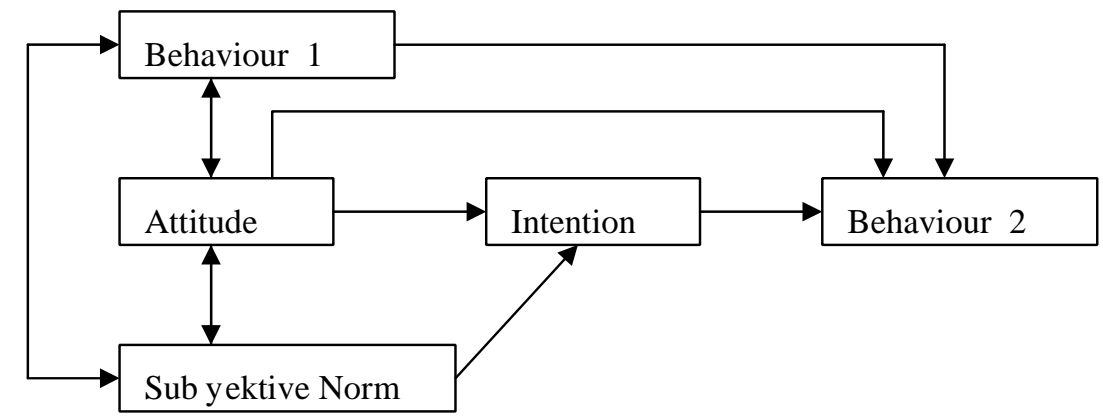

Gambar 2.4 Sikap yang Diusulkan Bentler dan Speckart

Bentler dan Speckart setuju dengan pendapat Fishbein-Ajzen yang menyimpulkan bahwa sikap seseorang terhadap suatu perilaku dapat diperkirakan dengan mengalikan evaluasi dari masing masing konsekuensi perilaku dengan probabilitas subyektif untuk melakukan perilaku yang akan menunjukkan konsekuensi tersebut dan kemudian menjumlahkan keseluruhan hasil perkalian yang diperoleh.

Sedangkan norma subyektif menurut Bentler dan Speckert adalah suatu pengukuran pengaruh lingkungan sosial dalam berperilaku, yang dapat disamakan dengan keyakinan individu berkaitan dengan apakah referen tersebut penting baginya dan ia harus melakukan perilaku tersebut. Norma subyektif seseorang terhadap perilaku dapat ditentukan dengan mendapatkan keyakinan dari individu yang berkaitan dengan masing-masing referen yang kemudian mengalikan tiaptiap nilai keyakinan dengan motivasi untuk mengikuti referen tertentu dan terakhir menjumlahkan hasil perkalian tersebut.

Niat berperilaku didefinisikan sebagai probabilitas subyektif yang dimiliki seseorang sehingga ia akan melaksanakan perilaku tertentu. Walaupun beberapa faktor mungkin mempengaruhi kekuatan hubungan niat-perilaku, niat berperilaku dikarakteristikkan oleh Bentler dan Speckart prediktor aktivitas yang baik (Bentler \& Speckart, 1979:453).

\section{Analisis Masalah}

Pada tahap ini diharapkan dapat menghasilkan analisis permasalahan yang ada, berupa kendalakendala dan permasalahan yang terjadi dalam proses pengelolaan Aplikasi sistem informasi sebelumnya, sehingga penulis dapat mencari solusi dari permasalahan tersebut. Untuk mencari solusi dari permasalahan yang ada, penulis mempelajari secara rinci bagaimana sistem yang sedang berjalan.

\section{Metodologi}

\subsection{Alur Penelitian}

Tahapan dalam penulisan ini dimulai dari identifikasi masalah dan studi literatur yang dilaksanakan, kemudian di tahap kedua, tahap di mana penulis melakukan analisis dan pengumpulan data. Tahap ketiga merupakan pembuatan evaluasi dari analisis dari temuan pada tahapan sebelumnya juga membuat kesimpulan dari temuan yang didapat di mana akan dilaksanakan. Ada pun kegiatan tersebut akan dijabarkan sebagai berikut:

1. Identifikasi Masalah. Pada tahapan ini dilakukan penggalian informasi seputar pencacatan aset pada Biro SARPRAS POLDA Jambi untuk mengetahui masalah-masalah yang ada.

2. Studi Literatur. Pada bagian ini penulis melakukan ulasan dan studi mengenai aset dengan metode TAM untuk meningkatkan pemahaman pada topik penelitian juga melakukan peninjauan pustaka pada penelitian sejenis untuk memperoleh gambaran pada konteks penelitian yang berbeda

3. Membuat Laporan. Pada tahap ini penyusunan laporan skripsi dikerjakan beriringan dengan dilakukannya dengan tahap-tahap sebelumnya.

\subsection{Metode Pengumpulan Data}


Pada penelitian ini, teknik pengumpulan data yang digunakan adalah field research dengan wawancara dan pengamatan lapangan, selanjutnya pengumpulan data dilakukan juga dengan library research dengan kuisioner.

\section{Pembahasan}

Penelitian ini bertujuan menguji Technology Acceptance Model atas analisis Efektifitas aplikasi sistem informasi Aset Polri pada Biro Sarpras Polda Jambi. Sampel penelitian ini adalah sebanyak 100 Operator pada Polda Jambi dan Jajaran yang meliputi Satuan Kerja dilingkungan Polda Dan 10 Polres/ta Jajaran. Penentuan sample dilakukan dengan proportional sampling yaitu metode pengambilan sampel secara proposional. Dalam penyebaran kuesioner ini dengan 100 kuesioner dan dikembalikan dalam jumlah yang sama dengan jawaban yang relatif berbeda-beda terhadap variabel-variabel penelitian sehingga dapat dilakukan pengukuran terhadap hasil jawaban dari masing-masing responden.

\section{Frekuensi Jawaban Responden}

Analisis deskriptif dalam penelitian ini bertujuan untuk mengetahui bagaimana tanggapan responden terhadap variabel-variabel penelitian. Analisis dilakukan dengan menginterprestasikan kecenderungan responden dalam menjawab pertanyaan pada masing-masing indikator.

Tabel 4.1 Tanggapan Terhadap Variabel Perceived Ease of Use

\begin{tabular}{|l|l|l|l|l|l|}
\hline \multirow{2}{*}{ Tanggapan Responden } & \multicolumn{5}{|c|}{ Operator } \\
\cline { 2 - 6 } & $\mathbf{1}$ & \multicolumn{1}{|c|}{$\mathbf{2}$} & $\mathbf{3}$ & $\mathbf{4}$ & $\mathbf{5}$ \\
\hline Sangat Tidak Setuju & & 1 & & & \\
\hline Tidak Setuju & 32 & 18 & 20 & 22 & 17 \\
\hline Tidak Pasti & 28 & 47 & 31 & 31 & 41 \\
\hline Setuju & 23 & 21 & 29 & 19 & 18 \\
\hline Sangat Setuju & 13 & 12 & 20 & 28 & 24 \\
\hline Total & $\mathbf{1 0 0}$ & $\mathbf{1 0 0}$ & $\mathbf{1 0 0}$ & $\mathbf{1 0 0}$ & $\mathbf{1 0 0}$ \\
\hline
\end{tabular}

Berdasarkan hasil uji frekuensi pada Variabel Perceived Ease Of Use, kebanyakkan responden memberikan jawaban Tidak pasti yang mengindikasikan bahwa Operator Aplikasi Sistem informasi Aset Polri tidak yakin pada kemampuannya dalam menggunakan Aplikasi.

Tabel 4.2 Tanggapan Terhadap Variabel Perceived Usefulnes

\begin{tabular}{|l|l|l|l|l|l|}
\hline \multirow{2}{*}{ Tanggapan Responden } & \multicolumn{5}{|c|}{ Operator } \\
\cline { 2 - 7 } & $\mathbf{1}$ & $\mathbf{2}$ & $\mathbf{3}$ & $\mathbf{4}$ & $\mathbf{5}$ \\
\hline Sangat Tidak Setuju & 1 & 1 & 3 & 1 & 3 \\
\hline Tidak Setuju & 18 & 21 & 20 & 32 & 27 \\
\hline Tidak Pasti & 24 & 30 & 27 & 35 & 25 \\
\hline Setuju & 21 & 19 & 21 & 13 & 32 \\
\hline Sangat Setuju & 31 & 29 & 29 & 19 & 13 \\
\hline Total & $\mathbf{1 0 0}$ & $\mathbf{1 0 0}$ & $\mathbf{1 0 0}$ & $\mathbf{1 0 0}$ & $\mathbf{1 0 0}$ \\
\hline
\end{tabular}

Berdasarkan hasil uji frekuensi pada Variabel Perceived Usefulnes, kebanyakkan responden memberikan jawaban Tidak pasti yang mengindikasikan bahwa Operator Aplikasi Sistem informasi Aset Polri tidak memiliki tingkat kepercayaan terhadap Aplikasi Sistem informasi Aset Polri.

Tabel 4.3 Tanggapan Terhadap Variabel Attitude Toward Using

\begin{tabular}{|l|l|l|l|l|l|}
\hline \multirow{2}{*}{ Tanggapan Responden } & \multicolumn{5}{|c|}{ Operator } \\
\cline { 2 - 7 } & $\mathbf{1}$ & $\mathbf{2}$ & $\mathbf{3}$ & $\mathbf{4}$ & $\mathbf{5}$ \\
\hline Sangat Tidak Setuju & 2 & & 1 & 1 & 5 \\
\hline Tidak Setuju & 39 & 37 & 18 & 40 & 39 \\
\hline Tidak Pasti & 17 & 30 & 42 & 17 & 35 \\
\hline Setuju & 17 & 18 & 17 & 23 & 10 \\
\hline Sangat Setuju & 22 & 15 & 22 & 19 & 11 \\
\hline Total & $\mathbf{1 0 0}$ & $\mathbf{1 0 0}$ & $\mathbf{1 0 0}$ & $\mathbf{1 0 0}$ & $\mathbf{1 0 0}$ \\
\hline
\end{tabular}


Berdasarkan hasil uji frekuensi pada Variabel Attitude Toward Using, kebanyakkan responden memberikan jawaban Tidak Setuju yang mengindikasikan bahwa Operator Aplikasi Sistem informasi Aset Polri tidak Menyukai AplikasiSistem Informasi Aset Polri.

Tabel 4.4 Tanggapan Terhadap Variabel Behavioral Intension to Use System

\begin{tabular}{|l|l|l|l|l|l|}
\hline \multirow{2}{*}{ Tanggapan Responden } & \multicolumn{5}{|c|}{ Operator } \\
\cline { 2 - 6 } & $\mathbf{1}$ & $\mathbf{2}$ & $\mathbf{3}$ & $\mathbf{4}$ & $\mathbf{5}$ \\
\hline Sangat Tidak Setuju & 1 & 3 & 3 & 1 & 2 \\
\hline Tidak Setuju & 31 & 32 & 35 & 24 & 35 \\
\hline Tidak Pasti & 31 & 19 & 21 & 29 & 15 \\
\hline Setuju & 13 & 33 & 13 & 27 & 17 \\
\hline Sangat Setuju & 23 & 13 & 28 & 19 & 31 \\
\hline Total & $\mathbf{1 0 0}$ & $\mathbf{1 0 0}$ & $\mathbf{1 0 0}$ & $\mathbf{1 0 0}$ & $\mathbf{1 0 0}$ \\
\hline
\end{tabular}

Berdasarkan hasil uji frekuensi pada Variabel Behavioral Intention To Use, kebanyakkan responden memberikan jawaban Tidak pasti yang mengindikasikan bahwa Operator Aplikasi Sistem informasi Aset Polri tidak memiliki minat untuk menggunakan Aplikasi Sistem informasi Aset Polri kembali.

\section{Analisis Statistik Deskriptif}

Analisis Deskriptif digunakan untuk mengetahui bagaimana jawaban responden terhadap variabelvariabel penelitian. Analisis ini dilakukan dengan menghitung nilai range teoritis, range empiris, nilai kisaran, mean dan standar deviasi serta kriteria sebagai berikut:

Tabel 4.5 Hasil Perhitungan Nilai Deskriptif Variabel

\begin{tabular}{|l|l|l|l|l|l|}
\hline \multicolumn{1}{|c|}{ Variabel } & \multicolumn{1}{|c|}{$\begin{array}{c}\text { Kisaran } \\
\text { Teoritis }\end{array}$} & $\begin{array}{c}\text { Kisaran } \\
\text { Empiris }\end{array}$ & \multicolumn{1}{|c|}{ Jarak } & \multicolumn{1}{c|}{ Mean } & $\begin{array}{c}\text { Std. } \\
\text { Deviation }\end{array}$ \\
\hline Perceived Ease Of Use & $5-31$ & $7-31$ & 8 & 22,49 & 4,715 \\
\hline Percieved Usefulnes & $5-31$ & $7-31$ & 8 & 22,43 & 4,511 \\
\hline Attitude Toward Using & $5-31$ & $7-31$ & 5,333 & 14,36 & 3,313 \\
\hline $\begin{array}{l}\text { Behavioral Intension to Use } \\
\text { System }\end{array}$ & $5-31$ & $7-31$ & 5,333 & 14,92 & 2,996 \\
\hline
\end{tabular}

Variabel Perceived Ease of Use

Variabel perceived ease of use terdiri dari 5 pertanyaan yang diukur dengan Skala Likert 1 sampai dengan 5. Berdasarkan perhiungan didapatkan nilai krieria sebagai berikut :

Berdasarkan perhitungan didapatkan nilai kriteria sebagai berikut:

Tabel 4.6 Kriteria Variabel Perceived Ease of Use

\begin{tabular}{|c|c|l|}
\hline Variabel & Range & \multicolumn{1}{|c|}{ Kriteria } \\
\hline Perceived & $5-16$ & Rendah \\
\hline Ease of Use & $16-23$ & Sedang \\
\cline { 2 - 3 } & $24-31$ & Tinggi \\
\hline
\end{tabular}

Berdasarkan hasil tabel 4.6 analisis deskritif diketahui bahwa nilai mean variabel perceived Ease of Use adalah sebesar 22,49 sehingga masuk dalam kriteria sedang. Nilai standar deviasi yang lebih tingi dari $20 \%$ nilai mean mengindikasikan bahwa jawaban respoden pada variabel perceived Ease of Use relatif heterogen. Nilai jawaban sedang mengindikasikan bahwa operator tidak yakin sepenuhnya apakah aplikasi sistem informasi aset polri bermanfaat bagi mereka dalam menyelesaikan tugas.

Variabel Perceived Usefulnes

Variabel perceived usefulnes terdiri dari 5 pertanyaan yang diukur dengan Skala Likert 1 sampai dengan 5. Berdasarkan perhiungan didapatkan nilai krieria sebagai berikut :

Berdasarkan perhitungan didapatkan nilai kriteria sebagai berikut:

Tabel 4.7 Kriteria Variabel Perceived Usefulnes

\begin{tabular}{|c|c|l|}
\hline Variabel & Range & \multicolumn{1}{c|}{ Kriteria } \\
\hline Perceived & $5-16$ & Rendah \\
Usefulnes & $16-23$ & Sedang \\
\cline { 2 - 3 }
\end{tabular}




\begin{tabular}{|l|l|l|}
\hline & Tinggi \\
\hline
\end{tabular}

Berdasarkan hasil tabel 4.7 analisis deskriotif diketahi bahwa nilai mean variabel Perceived Usefulnes adalah sebesar 22,43 sehingga masuk dalam kriteria sedang. Nilai standar deviasi yang lebih besar dari $20 \%$ nilai mean mengindikasikan bahwa jawaban responden pada variabel Perceived Usefulnes relatif heterogen. Nilai jawaban sedang mengindikasikan bahwa operator tidak yakin sepenuhnya apakah Aplikasi sistem informasi aset Polri mudah untuk dioperasikan.

Variabel Attitude Toward Using

Variabel attitude toward using terdiri dari 5 pertanyaan yang diukur dengan Skala Likert 1 sampai dengan 5. Berdasarkan perhitungan didapatkan nilai krieria sebagai berikut :

Berdasarkan perhitungan didapatkan nilai kriteria sebagai berikut:

Tabel 4.8 Kriteria Variabel Attitude Toward Using

\begin{tabular}{|c|c|l|}
\hline Variabel & Range & \multicolumn{1}{|c|}{ Kriteria } \\
\hline Attitude \\
Toward Using & $5-16$ & Rendah \\
\cline { 2 - 3 } & $16-23$ & Sedang \\
\cline { 2 - 3 } & $24-31$ & Tinggi \\
\hline
\end{tabular}

Berdasarkan hasil tabel 4.8 analisis deskriptif diketahui bahwa nilai mean variabel Attitude Toward Using adalah sebesar 14,36 sehingga masuk kriteria sedang. Nilai standar deviasi yang lebih besar dari $20 \%$ nilai mean mengindikasikan bahwa jawaban responden padad variabel Attitude Toward Using relatif heterogen. Nilai jawaban sedang mengindikasikan bahwa operator ragu apakah mereka sepenuhnya suka terhadap Aplikasi Sistem informasi Aset Polri.

Variabel Behavoral Intention To Use

Variabel Behavoral Intention To Use terdiri 5 pertanyaan yang diukur dengan Skala Likert 1 sampai dengan 5. Berdasarkan perhiungan didapatkan nilai krieria sebagai berikut :

Berdasarkan perhitungan didapatkan nilai kriteria sebagai berikut:

Tabel 4.9 Kriteria Variabel Behavioral Intention To Use

\begin{tabular}{|c|c|l|}
\hline Variabel & Range & \multicolumn{1}{|c|}{ Kriteria } \\
\hline \multirow{2}{*}{$\begin{array}{c}\text { Behavoral Intention } \\
\text { To Use }\end{array}$} & $5-16$ & Rendah \\
\cline { 2 - 3 } & $16-23$ & Sedang \\
\cline { 2 - 3 } & $24-31$ & Tinggi \\
\hline
\end{tabular}

Berdasarkan hasil tabel 4.9 analisis deskritif diketahui bahwa nilai mean variabel behavioral intension to use system adalah sebesar 14,92 sehingga masuk dalam kriteria tinggi. Nilai standar deviasi yang lebih besar dari $20 \%$ nilai mean mengindikasikan bahwa jabawan responden pada variabel behavioral intension to use system relatif heterogen.

\section{Persamaan Model Struktural dan Model Pengukuran}

Model yang telah disajikan dalam bentuk path diagram di aas, kemudian dinyatakan dalam persamaanpersamaan struktural dan persamaan yang menyatakan spesifikasi model pengukuran (measurement model). Persamaan struktural yang disajikan untuk mengkonversi path diagram di atas dirumuskan sebagai berikut:

Tabel 4.10. Model Persamaan Struktural

Perseived usefullness $=\beta_{1}$ perceived ease of use

Perceived ease of use

Attitude $=\beta_{2}$ perceived usefullness $+\beta_{1}$ perceived ease of use

Behavioral intension of use $=\beta_{2}$ perceived usefullness $+\beta_{3}$ Attitude

Tabel 4.10 diatas menjelaskan tiga persamaan yang dapat dibentuk model penelitian. Model 1 menjelaskan bahwa Perceived usefulnes dipengaruhi oleh Perceived ease of use. Model 2 menunjukan 
bahwa Attitude dipengaruhi oleh perceived usefulnes dan perceived ease of use. Pada model 3 menjelaskan bahwa behavioral intension of use di pengaruhi oleh perceived usefulnes dan attitude.

Tabel 4.11 Model Pengukuran

\begin{tabular}{|l|}
\hline \multicolumn{1}{|c|}{ Variabel Endogen } \\
\hline $\mathrm{X} 1=\lambda 1$ perceived usefullness $+\mathrm{e} 16$ \\
\hline $\mathrm{X} 2=\lambda 2$ perceived usefullness $+\mathrm{e} 17$ \\
\hline $\mathrm{X} 3=\lambda 3$ perceived usefullness $+\mathrm{e} 18$ \\
\hline $\mathrm{X} 4=\lambda 4$ perceived usefullness $+\mathrm{e} 19$ \\
\hline $\mathrm{X} 5=\lambda 5$ perceived usefullness $+\mathrm{e} 20$ \\
\hline $\mathrm{X} 6=\lambda 6$ perceived ease of use $+\mathrm{e} 1$ \\
\hline $\mathrm{X} 7=\lambda 7$ perceived ease of use $+\mathrm{e} 2$ \\
\hline $\mathrm{X} 8=\lambda 8$ perceived ease of use $+\mathrm{e} 3$ \\
\hline $\mathrm{X} 9=\lambda 9$ perceived ease of use $+\mathrm{e} 4$ \\
\hline $\mathrm{X} 10=\lambda 10$ perceived ease of use $+\mathrm{e} 5$ \\
\hline $\mathrm{X} 11=\lambda 11$ attitude $+\mathrm{e} 6$ \\
\hline $\mathrm{X} 12=\lambda 12$ attitude $+\mathrm{e} 7$ \\
\hline $\mathrm{X} 13=\lambda 13$ attitude $+\mathrm{e} 8$ \\
\hline $\mathrm{X} 14=\lambda 14$ attitude $+\mathrm{e} 9$ \\
\hline $\mathrm{X} 15=\lambda 15$ attitude $+\mathrm{e} 10$ \\
\hline $\mathrm{X} 16=\lambda 16$ behavioral intension to use $+\mathrm{e} 11$ \\
\hline $\mathrm{X} 17=\lambda 17$ behavioral intension to use $+\mathrm{e} 12$ \\
\hline $\mathrm{X} 18=\lambda 18$ behavioral intension to use $+\mathrm{e} 13$ \\
\hline $\mathrm{X} 19=\lambda 19$ behavioral intension to use $+\mathrm{e} 14$ \\
\hline $\mathrm{X} 20=\lambda 20$ behavioral intension to use $+\mathrm{e} 15$ \\
\hline
\end{tabular}

Uji Normalisasi Data

Pengujian normalisasi dilakukan dengan mengamati nilai skewness data yang digunakan, apabila nilai CR pada skewness data berada pada rentang antara +- 2,58 pada tingkat signifikansi 0,05. Hasil pengujian normalitas data ditampilkan pada Tabel 413. Berikut ini:

Tabel 4.13 Normalitas Data

\begin{tabular}{|l|rrrrrr|}
\hline Variable & $\min$ & Max & skew & c.r. & kurtosis & c.r. \\
\hline a5 & 2.000 & 6.000 & .317 & 1.292 & -.994 & -2.028 \\
b5 & 1.000 & 6.000 & .057 & .235 & -.807 & -1.647 \\
b4 & 1.000 & 5.000 & .461 & 1.883 & -.978 & -1.997 \\
b3 & 1.000 & 7.000 & -.002 & -.008 & -.751 & -1.533 \\
b2 & 1.000 & 6.000 & .067 & .272 & -1.180 & -2.410 \\
d5 & 1.000 & 5.000 & -.157 & -.643 & -1.216 & -2.483 \\
d4 & 1.000 & 5.000 & .028 & .112 & -1.560 & -3.183 \\
d3 & 1.000 & 5.000 & .045 & .183 & -1.103 & -2.252 \\
d2 & 1.000 & 5.000 & .180 & .736 & -1.428 & -2.914 \\
d1 & 1.000 & 5.000 & .011 & .046 & -1.154 & -2.356 \\
c5 & 1.000 & 5.000 & .302 & 1.233 & -1.175 & -2.398 \\
c4 & 1.000 & 5.000 & .655 & 2.673 & -.218 & -.446 \\
c3 & 1.000 & 5.000 & .285 & 1.163 & -1.368 & -2.793 \\
c2 & 1.000 & 5.000 & .212 & .867 & -.951 & -1.942 \\
c1 & 2.000 & 5.000 & .522 & 2.130 & -1.001 & -2.043 \\
a4 & 1.000 & 5.000 & .268 & 1.093 & -1.371 & -2.799 \\
a3 & 2.000 & 7.000 & .243 & .992 & -.843 & -1.721 \\
a2 & 2.000 & 5.000 & .027 & .110 & -1.128 & -2.303 \\
a1 & 1.000 & 5.000 & .316 & 1.292 & -.452 & -.922 \\
Multivariate & 2.000 & 5.000 & .390 & 1.592 & -1.001 & -2.043 \\
\hline & & & & & 61.535 & 10.372 \\
\hline
\end{tabular}


Nilai CR adalah nilai rasio kritis (critical ratio) atau nilai batas sebuah data dinyatakan normal. Sebuuah data dinyatakan beerdistribusi normal apabila nilai CR baik pada CR skeweness maupun CR kurtosis secara absolut bernilai kurang dari 2,58. Dari hasil pengolahan data yang ditampilkan pada abel di atas, diketahui banyak nilai pada kolom CR skewness yang lebih besar dari +- 2,58, hal ini mengidentifikasikan bahwa data penelitian tidak berdistribusi normal sempurna, sehingga digunakan metode General Least Square.

\section{Evaluasi atas Multikolinearitas dan Singularitas}

Indikasi adanya multikolinearitas dan singularitas dapat diketahui melalui nilai determinan matriks kovarians yang benar-benar kecil, atau mendekati nol. Dari hasil pengolahan data nilai determinan matriks kovarians sample adalah sebagai berikut:

Determinant of sample covariance matrix $=$

Dari hasil diatas diketahui bahwa determinant of sample covariance matrix $=$ tidak sama dengan 0 . Dengan demikian dapt disimpulkan bahwa daa penelitian ini terbebas dari multikolinieritas dan singularitas.

\section{Analisis Faktor Konfirmatori (Confirmatory Factor Analysis)}

Setelah dilakukan uji asumsi, maka langkah berikutnya dilakukan uji analisis faktor Confimatory konstruk. Tahapan ini menjelaskan pengukuran atas dimensi-dimensi yang membentuk variabel laten dalm model penelitian.

Tujuan dari analisis konfimatory adalah bentuk menguji unidimensionalitas dari dimensi-dimensi pembentuk masing-masing variabel laten. Pada tahap ini, model akan mengkonfirmasi apakah variabel yang diminati dapat mencerminkan faktor yang dianalisisnya.

\section{Variabel Perceived Ease of Use}

Berdasarkan khasil analisis konfimatory didapatkan hasil sebagai berikut:

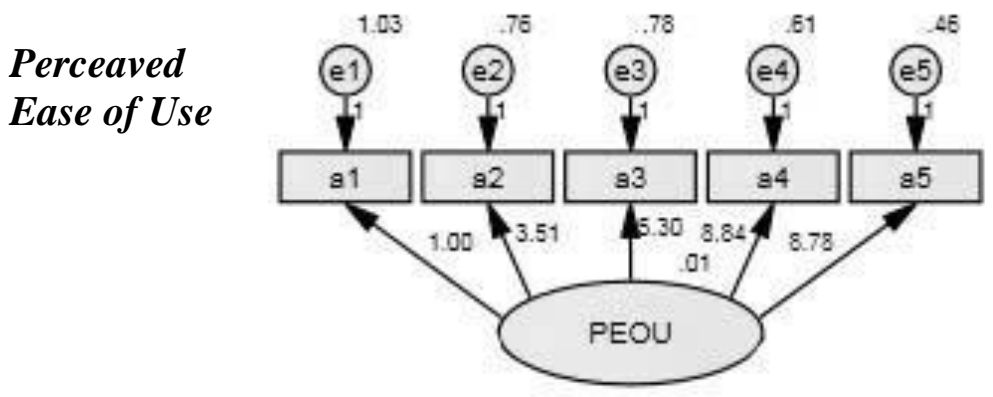

Gambar 4.16 Measurement Model Perceived Ease of Use

Tabel 4.14 Hasil CFA Perceived Ease of Use

\begin{tabular}{|l|rrrcc|}
\hline & Estimate & S.E. & C.R. & P & Label \\
\hline e1 & 1.032 & .147 & 7.015 & $* * *$ & par_27 \\
e2 & .761 & .114 & 6.663 & $* * *$ & par_28 \\
e3 & .785 & .126 & 6.241 & $* * *$ & par_29 \\
e4 & .609 & .142 & 4.291 & $* * *$ & par_30 \\
e5 & .461 & .125 & 3.690 & $* * *$ & par_46 \\
\hline
\end{tabular}

Variabel Perceived Usefulnes

Berdasarkan khasil analisis konfimatory didapatkan hasil sebagai berikut:

\section{Perceived Usefulnes}

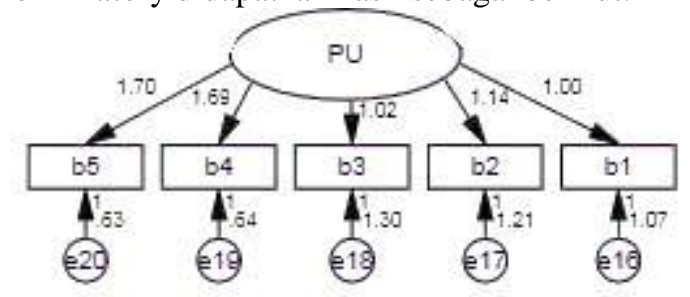


Gambar 4.17 Measurement Model Perceived Usefulnes

Tabel 4.15 Hasil CFA Perceived Usefulnes

\begin{tabular}{|l|rrrrr|}
\hline & Estimate & S.E. & C.R. & P & Label \\
\hline e16 & 1.069 & .166 & 6.444 & $* * *$ & par_41 \\
e17 & 1.214 & .194 & 6.266 & $* * *$ & par_42 \\
e18 & 1.296 & .197 & 6.587 & $* * *$ & par_43 \\
e19 & .636 & .129 & 4.940 & $* * *$ & par_44 \\
e20 & .625 & .127 & 4.926 & $* * *$ & par_45 \\
\hline
\end{tabular}

\section{Variabel Attitude}

Attitude

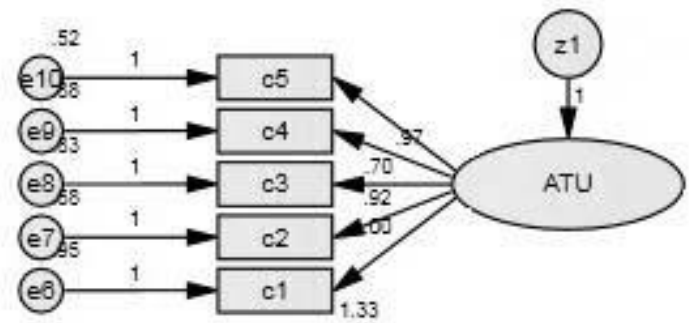

Gambar 4. 18 Measurement Model Attitude

Tabel 4.16 Hasil CFA Attitude

\begin{tabular}{|l|rrrrr|}
\hline & Estimate & S.E. & C.R. & P & Label \\
\hline e6 & .953 & .161 & 5.925 & $* * *$ & par_31 \\
e7 & .678 & .119 & 5.688 & $* * *$ & par_32 \\
e8 & .831 & .131 & 6.360 & $* * *$ & par_33 \\
e9 & .878 & .145 & 6.033 & $* * *$ & par_34 \\
e10 & .522 & .107 & 4.859 & $* * *$ & par_35 \\
\hline
\end{tabular}

Variabel Behavioral Inension to Use System

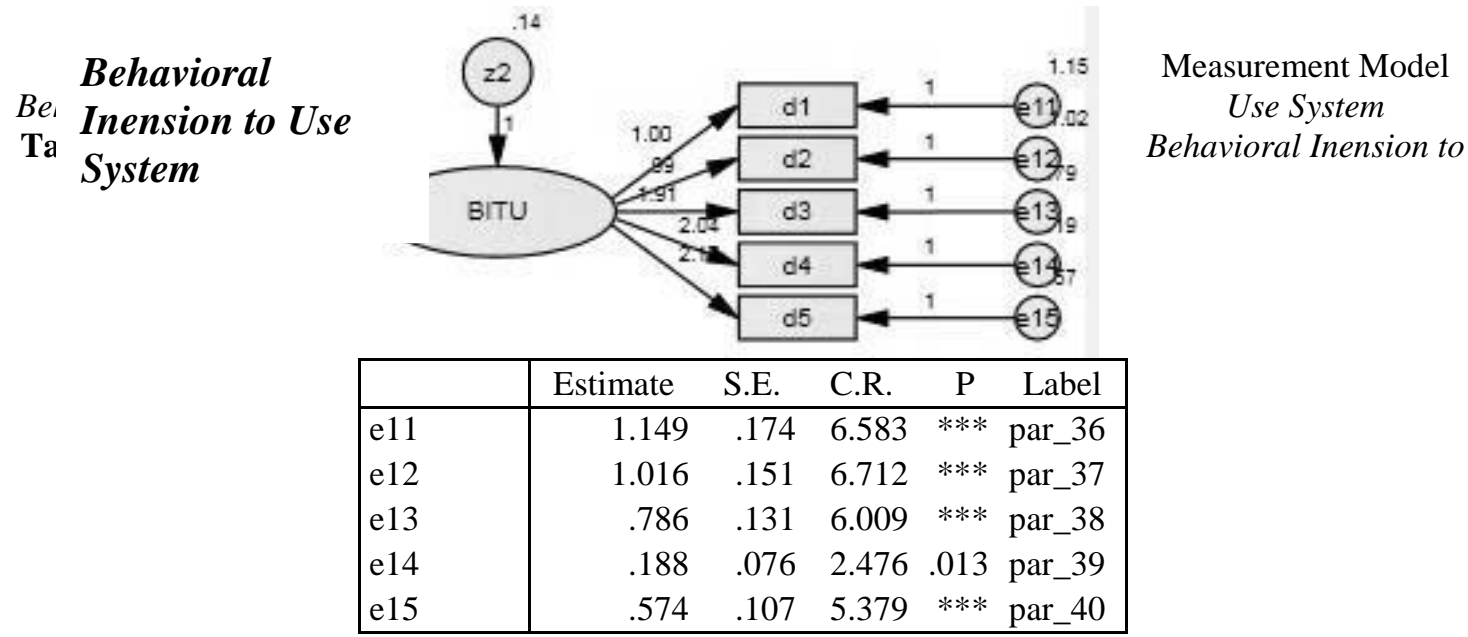

Relibility Analysis

Uji reliability digunakan untuk mengetahui sejauh mana tingka konsistensi sebuah instrumen. Suatu angket dinyatakan reliabel apabila jawaban seseorang terhadap pertanyaan konsisten dari waku ke waktu. Uji reliabilitas ini dilakukan dengan menggunakan SPSS 11.5 for windows.

Uji relibilitas variabel Perceived Ease of Use menghasilkan koefisien alpha sebesar 0,0000 yang menunjukkan bahwa Perceived Ease of Use dinyatakan cukup handal atau reliabel karena alpha $>0,7$. sehingga disimpulkan bahwa insrumen layak digunakan untuk penelitian. 
Uji relibilitas variabel Perceived Usefulnes menghasilkan koefisien alpha sebesar 0,0000 yang menunjukkan bahwa Perceived Usefulnes dinyatakan cukup handal atau reliabel karena alpha >0,7 . sehingga disimpulkan bahwa insrumen layak digunakan untuk penelitian.

Uji relibilitas variabel Attitude Toward Using menghasilkan koefisien alpha sebesar 0,0000 yang menunjukkan bahwa Attitude Toward Using dinyatakan cukup handal atau reliabel karena alpha $>0,7$. sehingga disimpulkan bahwa insrumen layak digunakan untuk penelitian.

Uji relibilitas variabel Behavioral Inention to Use menghasilkan koefisien alpha sebesar 0,0000 yang menunjukkan bahwa Behavioral Inention to Use dinyatakan cukup handal atau reliabel karena alpha $>0,7$ . sehingga disimpulkan bahwa insrumen layak digunakan untuk penelitian.

\section{Analisis Stuktural Equation Model (SEM) secara Full Model}

Analisis selanjutnya setelah analisis konfirmatori adalah analisis Struktural Equation Model (SEM) secara Full Model yang digunakan untuk menguji model dan kekuatan hubungan dari tiap variabel yang dikembangkan dalam penelitian ini. Seperti halnya dalam confirmatory factor analysis, pengujian pada Struktural equation Model juga dilakukan dengan dua macam pengujian, yaitu uji kesesuaian model serta uji signifikansi kausalitas melalui uji koefesien regresi. Hasil pengujian dapat dilihat pada gambar 4. Sebagai berikut:

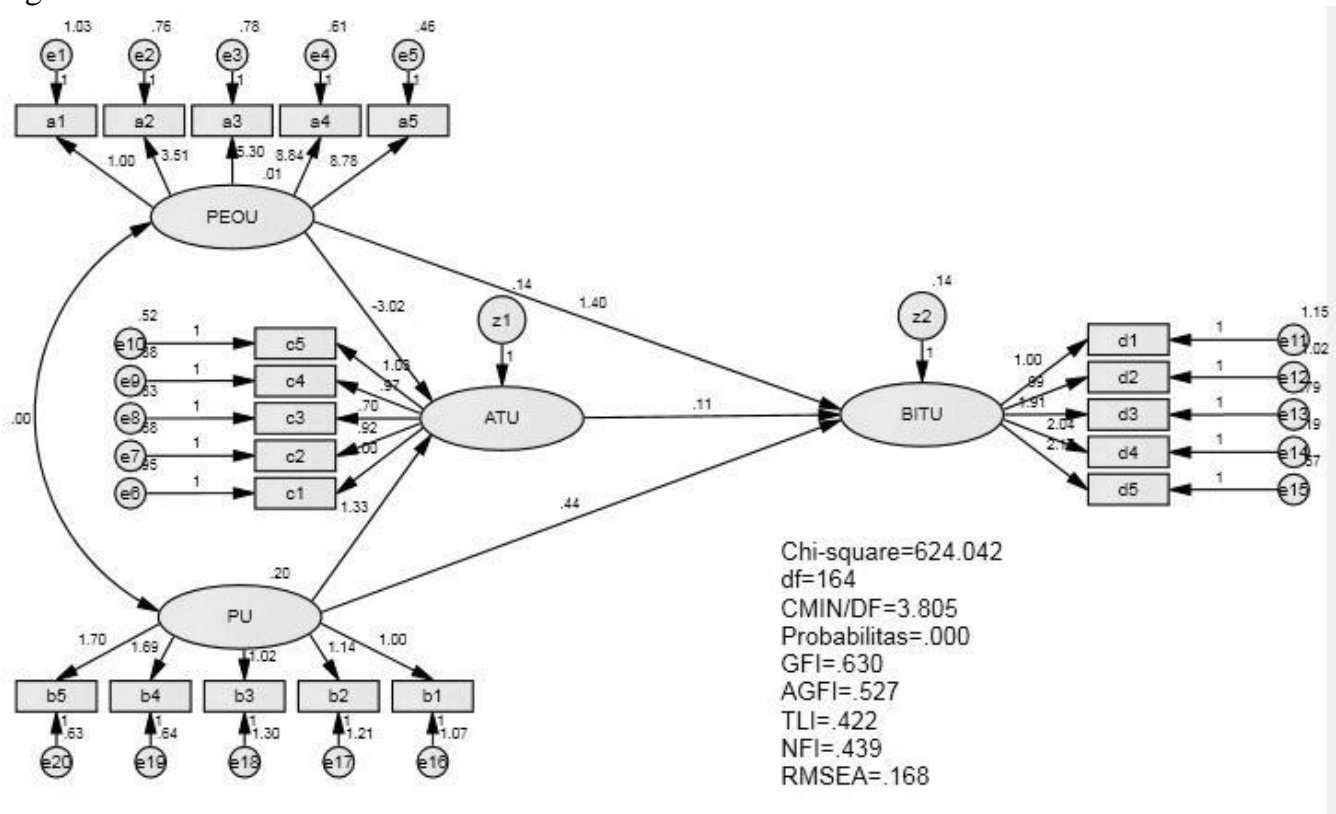

Gambar 4.20 Hasil Pengujian Strucural Equation Model

\section{Kesimpulan}

Berdasarkan analisis efektifitas aplikasi sistem informasi aset polri menggunakan metode technology acceptance model pada biro sarpras polda jambi maka dapat ditarik kesimpulan sebagai berikut :

1. Analisis efektifitas aplikasi sistem informasi aset polri menggunakan metode technology acceptance model pada biro sarpras polda jambi dengan sasaran utama penelitian yaitu hasil daro responden Operator sebagai pengguna Aplikasi menunjukkan bahwa operator masih belum persepsi yang sama mengenai minat, kemudahan, kegunaan dan pemanfaatan aplikasi ini sehingga dalam penilaian efektivitas Aplikasi ini masih sangat rendah.

2. Aplikasi sistem informasi aset polri merupakan Aplikasi yang dibuat oleh Pimpinan pusat dan dikirimkan keseluruh Jajaran untuk digunakan langsung oleh Pengguna akhir atau operator, tetapi dalam Aplikasi ini masih belum memberikan kemudahan kepada pengguna atau operator sehingga operator tidak memiliki minat untuk menggunakan aplikasi ini kembali salah satunya masalah yang dapat dilihat dari jawaban respoden dari kuesioner yang di sebarkan bahwa operator merasa tidak yakin pada aplikasi SIAP yang dimaksud. 
3. Dalam penelitian ini, diusulkan beberapa perbaikan Form dari menu Pendaftaran, menu mutasi aset, menu Pengurangan Aset, tampilan hasil pencariaan aset dan laporan aser, penulis dalam pengusulan rancangan ini lebih menekankan kepada Kode Aset diman selama ini kode aset tidak menjadi kunci utama dalam pencariaan data sehingga operator kesulitan dalam pencariaan data yang memiliki nama aset yang sama tetapi kose aset berbeda sehingga hasil dari laporan tidak sesuai dengan tujuan utama dibuatnya aplikasi ini.

4. Dalam penelitian ini, diusulkan beberapa perbaikan Form dari menu Pendaftaran, Menu Mutasi Aset, Menu Pengurangan Aset, Tampilan hasil pencarian Aset dan laporan Aset, Penulis dalam pengusulan rancangan ini lebih menekankan kepada Kode Aset dimana selama ini kode aset tidak menjadi kunci utama dalam pencarian data sehingga membuat pemakai dalam membaca untuk memudahkan operator dalam menggunakan Aplikasi secara membaca hasil dari laporan sesuai dengan yang tujuan utama dibuatnya aplikasi ini.

Saran

Berdasarkan penelitian yang telah dilakukan maka dapat dikemukakan saran-saran sebagai berikut : Dalam pemilihan atau penunjukan operator hendaknya Pimpinan memilih personil yang memiliki minat terhadap tehnologi informasi dan personil

\section{Daftar Pustaka}

[1] Davis, F.D. 1989. Perceived Usefulness, Perceived Ease of Use and User Acceptance of Information Technology, MIS Quarterly.

[2] Edy Nasrudin 2015 efektivitas sistem informasi manajemen dan akutansi barang milik negara. Jurnal akutansi vol 13 Nol.02

[3] Febri indra arza (2013) Pendekatan technology acceptance model dalam kesuksesan implemantasi sistem informasi manajemen daerah. Jurnal WRA, Vol 1, No.1

[4] Fran Sayeti dan Pulasna Purtarta 2016 Penerapan Technology acceptance model dalam pengujian model penerimaan sistem informasi keuangan daerah. Jurnal manajemen teori dan terapan no.03

[5] Laudon, Ken; Laudon, Jane P. 2012. Management Information Systems, 12th Edition. New York University:Pearson Education Limited.

[6] Manual Book Aplikasi Sistem informasi aset Polri tahun 2015 tentang panduan penggunaan Aplikasi SIAP

[7] McLeod, Jr. Raymond; \& P. Schell, George. 2007. Management Information Systems. Tenth Edition. New Jersey, United States of America: Pearson Prentice Hall.

[8] Ni nengah wartini dan I.G.W murjana Yasa (2016) analisis efektifitas sistem inforamasi keuangan daerah pemerintah kabupaten jembaran. E-jurnal ekonomi dan bisnis universitas udayana Vol 5.no.25

[9] O’Brien, A. James. 2006. Pengantar Sistem Informasi:Perspektif Bisnis dan Manajerial. Jakarta :Penerbit Salemba Empat.

[10] Peraturan Presiden Republik indonesia No. 27 tahun 2014 tentang Pengelolaan Barang milik negara.

[11] Shinta Eka Kartika 2009 analisis proses penerimaan sistem informasi iCons dengan menggunakan Technologi Accaptance model. Tesis Sains Akuntasi. 